\title{
PLATINO, a nine-year follow-up study of COPD in the city of São Paulo, Brazil: the problem of underdiagnosis*
}

\author{
PLATINO, estudo de seguimento de nove anos sobre DPOC na \\ cidade de São Paulo: o problema do subdiagnóstico
}

\section{Graciane Laender Moreira, Beatriz Martins Manzano, Mariana Rodrigues Gazzotti, Oliver Augusto Nascimento, Rogelio Perez-Padilla, Ana Maria Baptista Menezes, José Roberto Jardim}

\begin{abstract}
Objective: To determine the underdiagnosis rate in new COPD cases at the end of a nine-year follow-up period-in the study designated "Projeto Latino-Americano de Investigação em Obstrução Pulmonar" (PLATINO, Latin-American Pulmonary Obstruction Investigation Project)-and compare that with the underdiagnosis rate during the initial phase of the study, as well as to identify the clinical features exhibited by the subjects who were not diagnosed until the end of the follow-up phase. Methods: The study population comprised the 1,000 residents of the city of São Paulo, Brazil, who took part in the PLATINO study. Of those, 613 participated in the follow-up phase, during which the subjects were assessed with the same instruments and equipment employed in the initial phase of the study. We used the chi-square test or the independent sample t-test to analyze the underdiagnosis rate and to identify the characteristics of the subjects who were not diagnosed until the end of the follow-up phase. Results: The underdiagnosis rate for new COPD cases at the end of the nine-year follow-up period was 70.0\%. The underdiagnosis rate during the follow-up phase was $17.5 \%$ lower than that reported for the initial phase of the study. The subjects who were not diagnosed until the end of the follow-up phase presented with fewer respiratory symptoms, better pulmonary function, and less severe disease than did those previously diagnosed with COPD. Conclusions: The underdiagnosis rate for new COPD cases was lower in the follow-up phase of the study than in the initial phase. The subjects who were not diagnosed until the end of the follow-up phase of the PLATINO study presented with the same clinical profile as did those who were not diagnosed in the initial phase. These findings underscore the need for spirometry in order to confirm the diagnosis of COPD and provide early intervention.
\end{abstract}

Keywords: Pulmonary disease, chronic obstructive/diagnosis; Pulmonary disease, chronic obstructive/ epidemiology; Spirometry.

\section{Resumo}

Objetivo: Determinar a taxa de subdiagnóstico em novos casos de DPOC em uma amostra de pacientes após nove anos de seguimento do estudo "Projeto Latino-Americano de Investigação em Obstrução Pulmonar" (PLATINO) e compará-la à taxa de subdiagnóstico obtida na fase inicial do estudo, assim como identificar as características clínicas dos indivíduos subdiagnosticados na fase de seguimento. Métodos: A população desse estudo foi composta por 1.000 residentes na cidade de São Paulo que fizeram parte do estudo PLATINO. Desses, 613 indivíduos participaram da fase de seguimento. Os individuos foram avaliados utilizando-se os mesmos instrumentos e equipamentos na fase inicial do estudo. 0 teste do qui-quadrado ou o teste $t$ para amostras independentes foi utilizado para analisar a taxa de subdiagnóstico e identificar as características dos indivíduos subdiagnosticados durante a fase de seguimento. Resultados: A taxa de subdiagnóstico para novos casos da DPOC após nove anos de acompanhamento foi de 70,0\%. A taxa de subdiagnóstico na fase de seguimento foi 17,5\% menor que a da fase inicial do estudo. Os indivíduos subdiagnosticados na fase de seguimento apresentavam poucos sintomas respiratórios, função pulmonar mais preservada e menor gravidade da doença do que aqueles previamente diagnosticados com DPOC. Conclusões: A taxa de subdiagnóstico na fase de seguimento foi menor que a da fase inicial do estudo. Os indivíduos subdiagnosticados na fase de seguimento do estudo PLATINO apresentavam o mesmo perfil clínico daqueles subdiagnosticados na fase inicial. Esses achados reforçam a necessidade da utilização da espirometria para o diagnóstico de DPOC e possibilitar a intervenção precoce.

Descritores: Doença pulmonar obstrutiva crônica/diagnóstico; Doença pulmonar obstrutiva crônica/ epidemiologia; Espirometria.

*Study carried out at the Federal University of São Paulo, São Paulo, Brazil.

Correspondence to: José R Jardim. Rua Botucatu, 740, $3^{\circ}$ andar, Disciplina de Pneumologia, CEP 04023-062, São Paulo, SP, Brasil. Fax: 5511 5572-4301. E-mail: jardimpneumo@gmail.com

Financial support: This study received financial support from the Coordenação de Aperfeiçoamento de Pessoal de Nível Superior (CAPES, Office for the Advancement of Higher Education). Aché Laboratórios Farmacêuticos S.A., GlaxoSmithKline, and Takeda Brasil Farmacêutica. Submitted: 20 August 2013. Accepted, after review: 22 October 2013. 


\section{Introduction}

The study designated Projeto LatinoAmericano de Investigação em Obstrução Pulmonar (PLATINO, Latin-American Pulmonary Obstruction Investigation Project) is a populationbased epidemiological study in which the main objective was to investigate the prevalence of COPD in five major cities in Latin America. ${ }^{(1)}$

In the city of São Paulo, Brazil, the prevalence of COPD was $15.8 \%{ }^{(2)}$ Despite such high prevalence, a small proportion of subjects had actually been diagnosed with the disease. Only $12.5 \%$ of the patients with spirometry-diagnosed COPD already had an established clinical diagnosis of COPD, although a significant number of patients had well-defined symptoms of the disease. ${ }^{(3)}$ The main factor related to underdiagnosis is the infrequent use of spirometry as a diagnostic tool. ${ }^{(4)}$

Misdiagnosis or undiagnosis makes it unlikely that effective interventions will occur. This becomes evident when one examines again the findings from the PLATINO study, in which $83.3 \%$ of the subjects diagnosed with COPD in the city of São Paulo were found not to receive any pharmacological treatment. In addition, 47.3\% were not advised to stop smoking, and 72.4\% did not receive the flu vaccine. ${ }^{(5)}$

These findings show that COPD is an underdiagnosed and undertreated disease, which can have serious consequences for patients, such as higher morbidity and mortality, and can result in substantial economic impact on the health care system. Therefore, accurate, up-to-date information on COPD underdiagnosis is important in order to assist authorities and health professionals in implementing strategies for identifying and helping subjects with COPD, regardless of their degree of disease severity. ${ }^{(6)}$

The objective of the present study was to determine the underdiagnosis rate in new COPD cases at the end of a nine-year follow-up period and compare that with the underdiagnosis rate in prevalent COPD cases during the initial phase of the PLATINO study, as well as to determine the anthropometric characteristics, clinical features, and history of exposure to COPD risk factors of the subjects who went undiagnosed until the end of the follow-up phase of the PLATINO study, conducted in the city of São Paulo, Brazil, and compare them with those of the subjects previously diagnosed with COPD.

\section{Methods}

The present study population comprised the same subjects who originally took part in the initial phase of the PLATINO study in the city of São Paulo, Brazil $(n=1,000)$. Of those, a total of 613 subjects participated in this follow-up phase. The present study was approved by the Research Ethics Committee of the Universidade Federal de São Paulo (UNIFESP, Federal University of São Paulo) Hospital São Paulo (Ruling no. 04234/10), and, after being informed of the study and procedures, all subjects who agreed to participate gave written informed consent.

The information on the sampling process for the initial phase of the PLATINO study has been described in a previous study. ${ }^{(3)}$

All houses in which the subjects were interviewed in the initial phase of the PLATINO study were visited. The initial contact was made by one of four screeners, who confirmed whether the subjects still lived at those addresses, checked their telephone number, and informed them of the interviewers' visit.

With regard to the subjects who did not live in the same house (as that of the initial phase of the PLATINO study) anymore, the screeners sought to determine their whereabouts through information from neighbors or through inquiries in the neighborhood businesses. The names of those whose whereabouts was unknown were looked up in the registry of deaths within the state of São Paulo and other Brazilian states. All data obtained by the screeners were sent to the coordinating body responsible for organizing the files for the subsequent scheduling of interviews.

Before performing the field evaluation, all interviewers (14 physiotherapy undergraduates and physiotherapists) attended a training course, which included administering the questionnaire and performing spirometry, taught by the São Paulo team. Once the coordinating body was assured that the interviewers were qualified to perform the evaluations, a pilot study was conducted to clarify issues that could arise during the fieldwork, thereby ending the training phase for the interviewers. Once the pilot study was completed, the scheduling of visits (which was performed by the supervisors) actually began, and the respondents were subsequently visited by two interviewers.

At the respondent's house, the researchers first required written informed consent from the subject 
and, if the subject agreed to participate in the study, they proceeded to data collection, according to the following sequence: anthropometric assessment; completion of the questionnaire with exclusion criteria for participation in spirometry ${ }^{(1)}$; pre-bronchodilator spirometry; administration of a portion of the main questionnaire (in the first 15 minutes after bronchodilator administration); post-bronchodilator spirometry; administration of the remainder of the main questionnaire.

The main questionnaire administered in this follow-up phase was the same as that used in the initial phase of the PLATINO study ${ }^{(1)}$ (a combined version of the American Thoracic Society-Division of Lung Disease questionnaire, ${ }^{(7)}$ the European Community Respiratory Health Survey 11 questionnaire, ${ }^{(8)}$ and the Lung Health Study questionnaire) added with new questions on smoking, diagnosis, asthma, physical activity, sleep, and depression.

The diagnosis of COPD was confirmed by spirometry, which was performed before and after bronchodilator use, in accordance with the American Thoracic Society/European Respiratory Society guidelines. ${ }^{(9)}$ Spirometric measurements were taken with a portable battery-powered spirometer and an ultrasound system (EasyOne ${ }^{\mathrm{TM}}$; Medical Technologies, Chelmsparad, MA, USA and NDD Medizintechnik AG, Zurich, Switzerland), identical to those used in the initial phase of the PLATINO study. Participants performed up to 15 forced expiratory maneuvers in order to achieve quality-A level, i.e., three acceptable maneuvers yielding the highest $\mathrm{FEV}_{1}$ and FVC values, without exceeding a difference of 150 L. Subsequently, an inhaled bronchodilator (albuterol, $200 \mu \mathrm{g}$ ) was administered, with the use of a 500-mL spacer, and, after 15 minutes, the test was repeated. All spirometric tests were performed with the subjects seated and wearing a nose clip and a disposable mouthpiece. Only the expiratory phase was recorded.

Disease severity, on the basis of pulmonary function data, was classified in accordance with the Global Initiative for Chronic Obstructive Lung Disease criteria. ${ }^{(10)}$

In order to identify diagnoses of COPD, the same three questions used in the initial phase of the PLATINO study were used: "Has your doctor ever told you that you have emphysema in the lungs?"; "Has your doctor ever told you that you have chronic bronchitis?", "Has your doctor ever told you that you have chronic obstructive pulmonary disease (COPD)?"

A case of underdiagnosis was defined as that in which the subject answered "no" to the first three questions and had a post-bronchodilator $\mathrm{FEV}_{1} / \mathrm{FVC}$ ratio $<0.7$.

The data collected during the follow-up phase of the PLATINO study were added to the original database of the initial phase of the study, which was conducted in 2003, in the city of São Paulo, Brazil. Data analysis was performed with the Statistical Package for the Social Sciences, version 17.0 (SPSS Inc., Chicago, IL, USA), and the level of statistical significance was set at $p<0.05$.

The underdiagnosis rate in new cases at the end of the nine-year follow-up period was assessed with the chi-square test, which was also used to compare the characteristics of the subjects who went undiagnosed until the end of the follow-up phase of the PLATINO study with those of the subjects with a prior diagnosis of COPD, when variables were categorical. For numerical variables, we used the t-test for independent samples. The characteristics investigated were as follows: gender; age; level of education; nutritional status; pulmonary function; disease severity; symptoms; quality of life; exposure to COPD risk factors (burning wood/dung or charcoal; smoking; and history of respiratory infections in childhood).

For continuous variables, the results are expressed as mean and standard deviation. Categorical variables are expressed as absolute values and as percentages, representing the number of cases in each category.

\section{Results}

The data regarding the follow-up phase of the PLATINO study in the city of São Paulo, Brazil, are shown in Figure 1.

Table 1 shows the rates of underdiagnosis and prior diagnosis of COPD in new (incident) COPD cases and in all COPD cases during the follow-up phase of the PLATINO study in the city of São Paulo, Brazil. It can be seen that $70.0 \%$ of the incident COPD cases and 62.3\% of all COPD cases during this follow-up phase had airflow obstruction but had no physiciandiagnosed COPD.

The underdiagnosis rates found for incident COPD cases (follow-up phase of the PLATINO study) and for prevalent COPD cases (initial phase of the PLATINO study), all of which were classified 


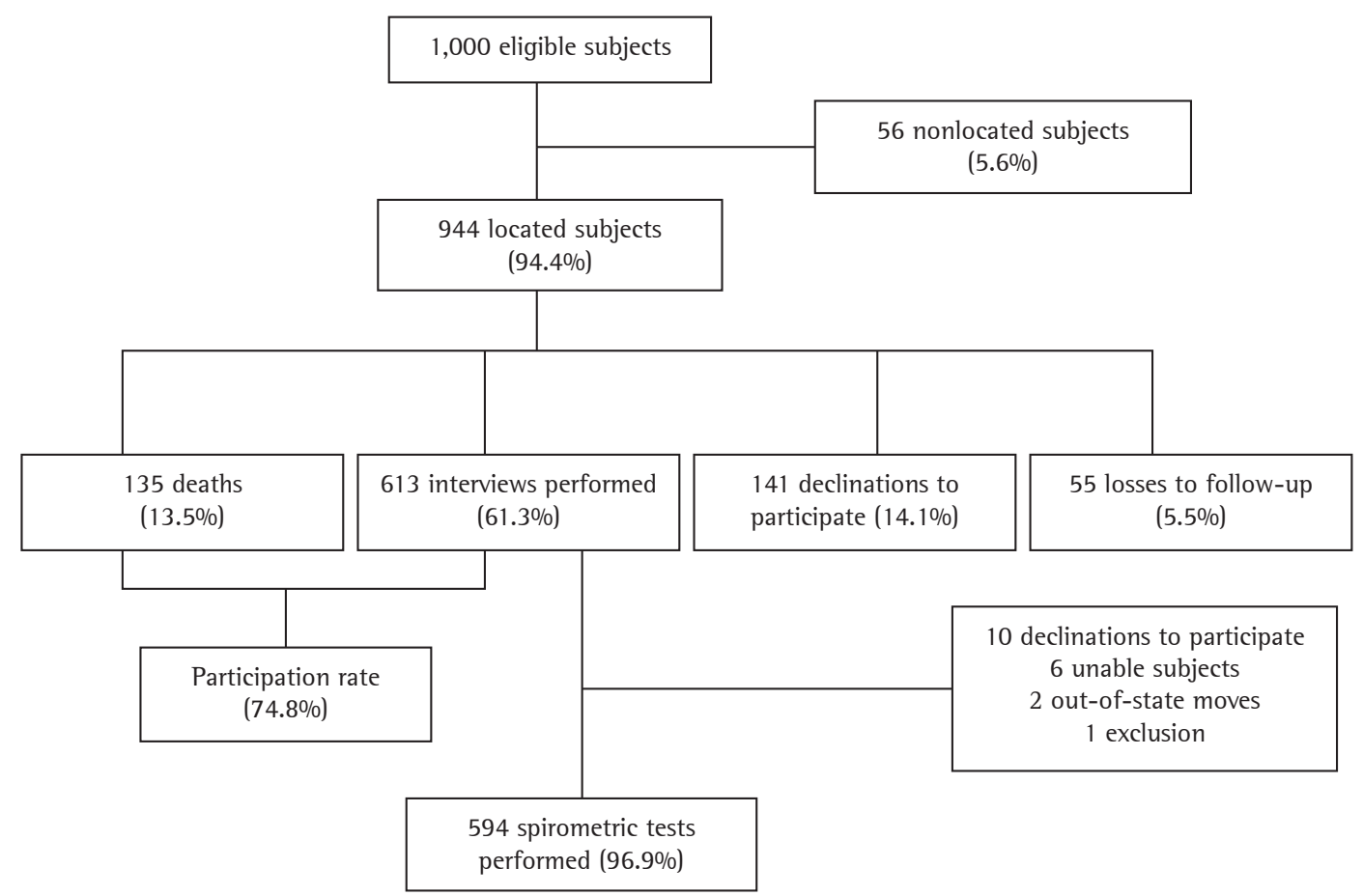

Figure 1 - Flowchart of the follow-up phase of the study designated Latin-American Pulmonary Obstruction Investigation Project in the city of São Paulo, Brazil.

Table 1 - Rates of underdiagnosis and prior diagnosis of COPD in new (incident) COPD cases and in all COPD cases during the follow-up phase of the study designated Latin-American Pulmonary Obstruction Investigation Project in the city of São Paulo, Brazil. ${ }^{a}$

\begin{tabular}{cll}
\hline \multicolumn{1}{c}{ Rate } & \multicolumn{1}{c}{ New cases } & \multicolumn{1}{c}{ All cases } \\
\cline { 2 - 3 } & \multicolumn{1}{c}{$(\mathrm{n}=20)$} & \multicolumn{1}{c}{$(\mathrm{n}=53)$} \\
\hline Underdiagnosis & $14(70.0)$ & $33(62.3)$ \\
Prior diagnosis & $6(30.0)$ & $20(37.7)$ \\
\hline
\end{tabular}

Values expressed as $n(\%)$.

by using an $\mathrm{FEV}_{1} / \mathrm{FVC}$ ratio $<0.7$ as the diagnostic criterion, are shown in Table 2. There was a $17.5 \%$ reduction in the underdiagnosis rate, with a consequent increase in the proportion of subjects with a prior diagnosis of COPD for incident cases as compared with prevalent cases.

The characteristics of the subjects who went undiagnosed until the end of the follow-up phase of the study were also evaluated. We describe the anthropometric and clinical characteristics of the subjects who went undiagnosed and of those with a prior diagnosis of COPD during the follow-up phase of the PLATINO study (Table 3), as well as their history of exposure to COPD risk factors (Table 4). It can be seen that there were no statistically significant differences between these groups in terms of anthropometric characteristics or exposure to COPD risk factors (Tables 2 and 4); however, the subjects who went undiagnosed had better pulmonary function, less severe disease, and fewer symptoms of phlegm and wheeze, as well as a higher proportion of one or none self-reported symptom.

\section{Discussion}

The findings of the follow-up phase of the PLATINO study in the city of São Paulo, Brazil, show that approximately two thirds of the new COPD cases and of all COPD cases diagnosed until the end of the nine-year follow-up period had not received a prior diagnosis of COPD, and that these subjects have a clinical profile with fewer respiratory symptoms, better pulmonary function, and less severe disease as compared with those previously diagnosed with COPD.

It has been predicted that COPD will be the third leading cause of death in the world by 2020, ${ }^{(11)}$ and, despite the significant socioeconomic impact of this disease, the underdiagnosis rates remain high. In the present study, the underdiagnosis rate was $70.0 \%$ for new COPD cases diagnosed until the end of the nine-year follow-up period and 
62.3\% for all of the participants in the follow-up phase of the PLATINO study. Similar rates have been reported in a study involving primary health

Table 2 - Rates of underdiagnosis and prior diagnosis of COPD in prevalent COPD cases during the initial phase of the study designated Projeto Latino-Americano de Investigação em Obstrução Pulmonar (PLATINO, Latin-American Pulmonary Obstruction Investigation Project) and in incident COPD cases during the follow-up phase of the PLATINO study, on the basis of the use of a post-bronchodilator $\mathrm{FEV}_{1} / \mathrm{FVC}$ ratio $<0.7$ as the diagnostic criterion. ${ }^{a}$

\begin{tabular}{ccc}
\hline \multicolumn{1}{c}{ Rate } & $\begin{array}{c}\text { (Prevalent) } \\
\text { COPD cases }\end{array}$ & $\begin{array}{c}\text { New (incident) } \\
\text { COPD cases }\end{array}$ \\
\hline Underdiagnosis & $126(87.5)$ & $14(70.0)$ \\
Prior diagnosis & $18(12.5)$ & $6(30.0)$ \\
\hline
\end{tabular}

${ }^{a}$ Values expressed as $n(\%)$. care clinics in the city of Aparecida de Goiânia, Brazil, ${ }^{(12)}$ and in cross-sectional epidemiological studies conducted in other countries, such as

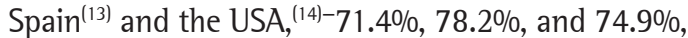
respectively-which shows that underdiagnosing COPD is not a problem observed only in developing countries. This means that spirometry is underused, a finding that has also been reported in a study conducted in Spain. ${ }^{(15)}$ Such a finding underscores the need for raising awareness of the importance of spirometry and for expanding its use in primary health care clinics, since spirometry is the best way to increase the detection of COPD, ${ }^{(16)}$ which prevents underdiagnosis of this disease. In addition, the adoption of simple and reasonable measures for use in interpreting spirometry can assist the health professional to use it to diagnose subjects, so that they can be properly treated.

Table 3 - Anthropometric and clinical characteristics of the subjects who went undiagnosed and of those with a prior diagnosis of COPD during the follow-up phase of the study designated Latin-American Pulmonary Obstruction Investigation Project in the city of São Paulo, Brazil. ${ }^{\text {a }}$

\begin{tabular}{|c|c|c|c|}
\hline \multirow[t]{2}{*}{ Characteristic } & Undiagnosed & With a prior diagnosis & \multirow[t]{2}{*}{$\mathrm{p}$} \\
\hline & $(\mathrm{n}=33)$ & $(\mathrm{n}=20)$ & \\
\hline Male gender & $17(53.1)$ & $13(65.0)$ & 0.39 \\
\hline Age, years ${ }^{b}$ & $67.2 \pm 10.3$ & $67.7 \pm 10.3$ & 0.87 \\
\hline Level of education, years ${ }^{b}$ & $3.9 \pm 4.4$ & $4.2 \pm 3.6$ & 0.76 \\
\hline $\mathrm{BMl},{ }^{\mathrm{b}} \mathrm{kg} / \mathrm{m}^{2}$ & $26.5 \pm 6.4$ & $26.7 \pm 7.9$ & 0.95 \\
\hline \multicolumn{4}{|l|}{ Pulmonary function ${ }^{\mathrm{b}}$} \\
\hline Post-BD FEV ${ }_{1}, \mathrm{~L}$ & $1.84 \pm 0.6$ & $1.45 \pm 0.7$ & 0.04 \\
\hline Post-BD FEV ${ }_{1}, \%$ predicted & $75.7 \pm 20.7$ & $58.5 \pm 20.6$ & 0.005 \\
\hline Post-BD FVC, L & $2.82 \pm 0.83$ & $2.46 \pm 1.1$ & 0.18 \\
\hline Post BD FVC, \% predicted & $87.0 \pm 21.6$ & $73.1 \pm 20.4$ & 0.026 \\
\hline Post-BD FEV $1 /$ FVC & $0.64 \pm 0.05$ & $0.58 \pm 0.10$ & 0.02 \\
\hline \multicolumn{4}{|l|}{ GOLD classification } \\
\hline 1 (mild; FEV $1 \geq 80 \%$ predicted) & $12(37.5)$ & $4(5.0)$ & 0.028 \\
\hline 2 (moderate; $50 \leq \mathrm{FEV}_{1}<80 \%$ predicted) & $17(53.1)$ & $8(40.0)$ & \\
\hline $3 / 4$ (severe/very severe; $\mathrm{FEV}_{1}<50 \%$ predicted) & $3(9.4)$ & $8(40.0)$ & \\
\hline \multicolumn{4}{|l|}{ Quality of life questionnaire ${ }^{\mathrm{b}}$} \\
\hline Physical domain & $46.3 \pm 10.5$ & $40.2 \pm 13.0$ & 0.07 \\
\hline Mental domain & $51.4 \pm 11.0$ & $48.0 \pm 10.9$ & 0.27 \\
\hline \multicolumn{4}{|l|}{ Presence of symptoms } \\
\hline Cough & $11(33.3)$ & $11(55.0)$ & 0.12 \\
\hline Phlegm & $9(27.3)$ & $13(65.0)$ & 0.007 \\
\hline Wheeze & $13(39.4)$ & $15(75.0)$ & 0.01 \\
\hline Dyspnea & $17(53.1)$ & 14 (73.7) & 0.14 \\
\hline \multicolumn{4}{|l|}{ Grouped symptoms } \\
\hline None & $7(21.8)$ & $1(5.3)$ & 0.021 \\
\hline 1 & $10(31.3)$ & $2(10.5)$ & \\
\hline 2 & $9(28.1)$ & $5(26.3)$ & \\
\hline$>2$ & $6(18.8)$ & $11(57.9)$ & \\
\hline
\end{tabular}

BMl: body mass index; post-BD: post-bronchodilator; and GOLD: Global Initiative for Chronic Obstructive Lung Disease. ${ }^{a}$ Values expressed as $\mathrm{n}(\%)$. ${ }^{\text {b}}$ Values expressed as mean \pm SD 
Table 4 - Characteristics of the subjects who went undiagnosed and of those with a prior diagnosis of COPD during the follow-up phase of the study designated Latin-American Pulmonary Obstruction Investigation Project in the city of São Paulo, Brazil, by exposure to COPD risk factors. ${ }^{a}$

\begin{tabular}{|c|c|c|c|}
\hline Characteristic & Undiagnosed & With a prior diagnosis & $\mathrm{p}$ \\
\hline & $(n=33)$ & $(n=20)$ & \\
\hline Exposure to burning wood & & & \\
\hline Yes & $24(72.7)$ & $15(75.0)$ & 0.94 \\
\hline No & $9(27.3)$ & $5(25.0)$ & \\
\hline Exposure to burning charcoal & & & \\
\hline Yes & $8(24.2)$ & $5(25.0)$ & 0.86 \\
\hline No & $25(75.8)$ & $15(75.0)$ & \\
\hline Exposure to dust & & & \\
\hline Yes & $22(66.7)$ & $17(89.5)$ & 0.07 \\
\hline No & $11(33.3)$ & $2(10.5)$ & \\
\hline History of respiratory infections & & & \\
\hline Yes & $1(3.0)$ & $0(0.0)$ & 0.44 \\
\hline No & $32(97.0)$ & $20(100.0)$ & \\
\hline Smoking & & & \\
\hline Never smokers & $11(33.3)$ & $6(30.0)$ & 0.89 \\
\hline Former smoker & $14(42.4)$ & $8(40.0)$ & \\
\hline Smoker & $8(24.2)$ & $6(30.0)$ & \\
\hline
\end{tabular}

${ }^{a}$ Values expressed as $n(\%)$.

However, a comparison of the underdiagnosis rate in new COPD cases during the follow-up phase of the PLATINO study with the underdiagnosis rate in prevalent COPD cases during the initial phase of the PLATINO study showed that there was a $17.5 \%$ reduction $(70 \%$ in incident cases vs. $87.5 \%$ in prevalent cases), with the proportion of diagnoses doubling (30.0\% in incident cases vs. $12.5 \%$ in prevalent cases). It is very likely that the larger number of current diagnoses is due to the increased dissemination of information on the disease by the media, as a result of the efforts of the medical society. In addition, since we made our facility available to the subjects who had abnormal pulmonary function test results in the initial phase of the PLATINO study for consultation with a pulmonologist, this might also have contributed to the reduction in the underdiagnosis rate. However, special efforts should be made so that subjects with COPD can be diagnosed, and, therefore, the costs and impact of this disease on patients can be minimized.

The subjects who went undiagnosed until the end of the follow-up phase of the PLATINO study in the city of São Paulo, Brazil, had fewer respiratory symptoms, better pulmonary function, and less severe disease than did those previously diagnosed with COPD.
Previous epidemiological studies ${ }^{(5,6,17)}$ and studies conducted in primary health care clinics $^{(18,19)}$ have reported these same characteristics in subjects who went undiagnosed. This shows that, even at the end of the nine-year follow-up period, the subjects who went undiagnosed had the same clinical profile, and the fact that they had few symptoms draws attention to the need for health professionals to use spirometry for diagnosis. It is of note that approximately $90 \%$ of the cases that went undiagnosed in the present study, considering the new COPD cases, had mild to moderate disease, showing that most of the subjects who went undiagnosed are in the initial stages of the disease, which makes early intervention possible.

One of the limitations of the present study is the rate of loss to follow-up, which exceeded $20 \%$. However, a European multicenter longitudinal study over a similar follow-up period reported a participation rate of $63.3 \% .{ }^{(20)} \mathrm{ln}$ addition, the group consisting of losses to follow-up and declinations to participate had the same clinical and pulmonary function characteristics as those of the participants in the follow-up phase of the PLATINO study. Another limitation might be due to the fact that the diagnosis of COPD was based on the Global Initiative for Chronic Obstructive lung Disease criterion $\left(\mathrm{FEV}_{1} / \mathrm{FVC}<0.7\right)$, because 
the use of this criterion can increase the rates of false-positive results in older subjects and might not detect the disease in younger subjects (false-positive results) ${ }^{(21)}$; therefore, the use of the lower limit of normality is recommended by some authors. ${ }^{(22,23)}$ It has recently been suggested that in disputed cases of airflow obstruction; i.e., cases with an $\mathrm{FEV}_{1} / \mathrm{FVC}$ ratio $<0.7$ and an $\mathrm{FEV}_{1} / \mathrm{FVC} \geq$ the lower limit of normality, subjects would not have clinically significant obstruction but would have a clinical profile characterized by important comorbidities, indicating that they could be at risk of developing COPD and should, therefore, be carefully followed. ${ }^{(24)}$ However, the best criterion for the diagnosis of airflow obstruction remains in dispute in the literature, ${ }^{(25,26)}$ and will continue so, since a recent longitudinal epidemiological study ${ }^{(27)}$ has suggested the use of $\mathrm{FEV}_{1} / \mathrm{FEV}_{6}$ as a criterion, because FVC varies with expiratory time during forced maneuvers required for spirometry.

We conclude that the underdiagnosis rate in new COPD cases identified during the follow-up phase of the PLATINO study in the city of São Paulo, Brazil, was 70.0\%. There was a $17.5 \%$ reduction in the underdiagnosis rate when we compared incident cases (follow-up phase of the PLATINO study) with prevalent cases (initial phase of the PLATINO study), and, even at the end of the nine-year follow-up period, the subjects who went undiagnosed continued to have the same clinical profile (better pulmonary function, less severe disease, and fewer symptoms).

The underdiagnosis rate of COPD identified in this population-based longitudinal epidemiological study was high, underscoring the need for raising awareness and expanding the use of spirometry in primary health care clinics.

\section{Acknowledgments}

We would like to thank the Associação LatinoAmericana de Tórax (ALAT, Latin American Chest Association) for academic support.

\section{References}

1. Menezes AM, Victora CG, Perez-Padilla R; PLATINO Team. The Platino project: methodology of a multicenter prevalence survey of chronic obstructive pulmonary disease in major Latin American cities. BMC Med Res Methodol. 2004;4:15. http://dx.doi.org/10.1186/14712288-4-15 PMid:15202950 PMCid:PMC442126

2. Menezes AM, Jardim JR, Pérez-Padilla R, Camelier A, Rosa F, Nascimento 0, Hallal PC. Prevalence of chronic obstructive pulmonary disease and associated factors: the PlATino Study in São Paulo, Brazil. Cad Saude Publica. 2005;21(5):1565-73. http://dx.doi.org/10.1590/ S0102-311X2005000500030 PMid:16158163

3. Menezes AM, Perez-Padilla R, Jardim JR, Mui-o A, Lopez MV, Valdivia G, et al. Chronic obstructive pulmonary disease in five Latin American cities (the PLATINO study): a prevalence study. Lancet. 2005;366(9500):1875-81. http://dx.doi.org/10.1016/S0140-6736(05)67632-5

4. Montes de Oca M, Tálamo C, Halbert RJ, Perez-Padilla R, Lopez MV, Mui-o A, et al. Health status perception and airflow obstruction in five Latin American cities: the PLATINO study. Respir Med. 2009;103(9):1376-82. http:// dx.doi.org/10.1016/j.rmed.2009.03.005 PMid:19364640

5. Nascimento OA, Camelier A, Rosa FW, Menezes AM, Pérez-Padilla R, Jardim JR, et al. Chronic obstructive pulmonary disease is underdiagnosed and undertreated in São Paulo (Brazil): results of the PLATINO study. Braz J Med Biol Res. 2007;40(7):887-95. http://dx.doi. org/10.1590/S0100-879X2006005000133 PMid:17653440

6. Tálamo C, de Oca MM, Halbert R, Perez-Padilla R, Jardim JR, Mui-o A, et al. Diagnostic labeling of COPD in five Latin American cities. Chest. 2007;131(1):60-7. http:// dx.doi.org/10.1378/chest.06-1149 PMid:17218557

7. Ferris BG. Epidemiology Standardization Project (American Thoracic Society). Am Rev Respir Dis. 1978;118(6 Pt 2):1-120. PMid:742764

8. European Community Respiratory Health Survey 11 Steering Committee. The European Community Respiratory Health Survey 11. Eur Respir J. 2002;20(5):1071-9. http://dx.doi. org/10.1183/09031936.02.00046802 PMid:12449157

9. Miller MR, Hankinson J, Brusasco V, Burgos F, Casaburi $\mathrm{R}$, Coates A, et al. Standardisation of spirometry. Eur Respir J. 2005;26(2):319-38. http://dx.doi.org/10.118 3/09031936.05.00034805 PMid:16055882

10. Global Initiative for Chronic Obstructive Lung Disease [homepage on the Internet]. Bethesda: Global Initiative for Chronic Obstructive lung Disease. [cited 2013 Aug 20]. Global Strategy for the Diagnosis, Management and Prevention of Chronic Obstructive Pulmonary Disease. Updated 2013. [Adobe Acrobat document, 99p.]. Available from: http://www.goldcopd.org/uploads/users/files/ GOLD_Report_2013_Feb20.pdf

11. Murray CJ, Lopez AD. Alternative projections of mortality and disability by cause 1990-2020: Global Burden of Disease Study. Lancet. 1997;349(9064):1498-504. http:// dx.doi.org/10.1016/S0140-6736(96)07492-2

12. Queiroz MC, Moreira MA, Rabahi MF. Underdiagnosis of COPD at primary health care clinics in the city of Aparecida de Goiânia, Brazil. J Bras Pneumol. 2012;38(6):692-9. http://dx.doi.org/10.1590/S1806-37132012000600003 PMid:23288113

13. Pe-a VS, Miravitlles M, Gabriel R, Jiménez-Ruiz CA, Villasante C, Masa JF, et al. Geographic variations in prevalence and underdiagnosis of COPD: results of the IBERPOC multicentre epidemiological study. Chest. 2000;118(4):981-9. http://dx.doi.org/10.1378/ chest.118.4.981

14. Coultas DB, Mapel D, Gagnon R, Lydick E. The health impact of undiagnosed airflow obstruction in a national sample of United States adults. Am J Respir Crit Care Med. 2001;164(3):372-7. http://dx.doi.org/10.1164/ ajrccm.164.3.2004029 PMid:11500335

15. Miravitlles M, de la Roza C, Morera J, Montemayor T, Gobartt E, Martín A, et al. Chronic respiratory symptoms, 
spirometry and knowledge of COPD among genera population. Respir Med. 2006;100(11):1973-80. http:// dx.doi.org/10.1016/j.rmed.2006.02.024 PMid:16626950

16. Mannino DM. Defining chronic obstructive pulmonary disease... and the elephant in the room. Eur Respir J. 2007;30(2):189-90. http://dx.doi. org/10.1183/09031936.00058707 PMid:17666553

17. Schirnhofer L, Lamprecht B, Firlei N, Kaiser B, Buist AS, Halbert RJ, et al. Using targeted spirometry to reduce non-diagnosed chronic obstructive pulmonary disease. Respiration. 2011;81(6):476-82. http://dx.doi. org/10.1159/000320251 PMid:20720402

18. Minas M, Hatzoglou C, Karetsi E, Papaioannou Al, Tanou K, Tsaroucha R, et al. COPD prevalence and the differences between newly and previously diagnosed COPD patients in a spirometry program. Prim Care Respir J. 2010;19(4):363-70. http://dx.doi.org/10.4104/ pcrj.2010.00034 PMid:20532466

19. Hill K, Goldstein RS, Guyatt GH, Blouin M, Tan WC, Davis LL, et al. Prevalence and underdiagnosis of chronic obstructive pulmonary disease among patients at risk in primary care. CMAJ. 2010;182(7):673-8. http:// dx.doi.org/10.1503/cmaj.091784 PMid:20371646 PMCid:PMC2855915

20. de Marco R, Accordini S, Marcon A, Cerveri 1, Antó JM, Gislason T, et al. Risk factors for chronic obstructive pulmonary disease in a European cohort of young adults. Am J Respir Crit Care Med. 2011;183(7):891-7. http:// dx.doi.org/10.1164/rccm.201007-11250C PMid:20935112
21. Celli BR, Halbert RJ, lsonaka S, Schau B. Population impact of different definitions of airway obstruction. Eur Respir J. 2003;22(2):268-73. http://dx.doi.org/10 .1183/09031936.03.00075102 PMid:12952259

22. Pellegrino R, Viegi G, Brusasco V, Crapo RO, Burgos F, Casaburi R, et al. Interpretative strategies for lung function tests. Eur Respir J. 2005;26(5):948-68. http://dx.doi. org/10.1183/09031936.05.00035205 PMid:16264058

23. Lung function testing: selection of reference values and interpretative strategies. American Thoracic Society. Am Rev Respir Dis. 1991;144(5):1202-18. http://dx.doi. org/10.1164/ajrccm/144.5.1202 PMid:1952453

24. Lamprecht B, Schirnhofer L, Kaiser B, Buist SA, Mannino DM, Studnicka M. Subjects with Discordant Airways Obstruction: Lost between Spirometric Definitions of COPD. Pulm Med. 2011;2011:780215. doi: 10.1155/2011/780215

25. Celli BR, Halbert RJ. Point: should we abandon FEV I $_{1}$ FVC $<0.70$ to detect airway obstruction? No. Chest. 2010;138(5):1037-40. http://dx.doi.org/10.1378/chest.102049 PMid:21051393

26. Enright P, Brusasco V. Counterpoint: should we abandon $\mathrm{FEV}_{1} / \mathrm{FVC}<0.70$ to detect airway obstruction? Yes. Chest. 2010;138(5):1040-2; discussion 1042-4. http://dx.doi. org/10.1378/chest.10-2052 PMid:21051394

27. Perez-Padilla R, Wehrmeister FC, Celli BR, Lopez-Varela MV, Montes de Oca M, Mui-o A, et al. Reliability of FEV1/ FEV6 to diagnose airflow obstruction compared with FEV1/FVC: the PLATINO longitudinal study. PLoS One. 2013;8(8):e67960. http://dx.doi.org/10.1371/journal. pone.0067960 PMid:23936297 PMCid:PMC3731337

\section{About the authors}

\section{Graciane Laender Moreira}

Physiotherapist. Federal University of São Paulo, São Paulo, Brazil.

\section{Beatriz Martins Manzano}

Physiotherapist. Federal University of São Paulo, São Paulo, Brazil.

Mariana Rodrigues Gazzotti

Professor. Department of Physical Therapy, São Camilo University Center, São Paulo, Brazil.

\section{Oliver Augusto Nascimento}

Attending Physician, Department of Pulmonology, Federal University of São Paulo, São Paulo, Brazil.

\section{Rogelio Perez-Padilla}

Professor. Instituto Nacional de Enfermedades Respiratórias, Mexico City, Mexico.

\section{Ana Maria Baptista Menezes}

Full Professor of Pulmonology. Department of Clinical Medicine, Federal University of Pelotas School of Medicine, Pelotas, Brazil.

\section{José Roberto Jardim}

Tenured Professor. Department of Pulmonology, Federal University of São Paulo, São Paulo, Brazil. 